\title{
HUBUNGAN KARAKTERISTIK SUBJEK, ASUPAN ZAT GIZI, DAN AKTIVITAS FISIK DENGAN KEKUATAN OTOT ANAK USIA SEKOLAH DI KABUPATEN PURWAKARTA
}

\author{
Naintina Lisnawati ${ }^{*}$, Irwan Haryanto ${ }^{2}$ \\ 1,2Sekolah Tinggi Ilmu Kesehatan Holistik Purwakarta \\ *Korespondensi: Jl. Veteran No. 272 Ciseureuh Purwakarta, Email: naintinalisnawati@gmail.com
}

\begin{abstract}
ABSTRAK
Latar Belakang : Kekuatan otot sangat penting untuk melakukan aktivitas dengan baik tidak terkecuali bagi anak usia sekolah. Kekuatan otot dipengaruhi oleh karakteristik subjek, asupan zat gizi, dan aktivitas fisik.

Tujuan : Menganalisis hubungan karakteristik subjek, asupan zat gizi, dan aktivitas fisik dengan kekuatan otot anak usia sekolah di Kabupaten Purwakarta.

Metode : Desain penelitian ini adalah cross sectional. Subjek penelitian adalah siswa Sekolah Menengah Pertama (SMP) Negeri 5 Purwakarta yang berjumlah 44 orang. Kekuatan otot diukur menggunakan Hand Dynamometer, lean body mass (LBM) menggunakan Bio Impedance Analysis (BIA), asupan gizi menggunakan Formulir Food Recall 2x24 jam, dan aktivitas fisik menggunakan Formulir Recall Aktivitas Fisik 24 jam. Analisis data menggunakan uji Pearson Product Moment dan Mann-Whitney Test.

Hasil : Aktivitas fisik subjek sebagian besar (75\%) tergolong ringan. Tidak ada hubungan usia $(p=0,228)$; jenis kelamin $(p=0,102)$; LBM $(p=0,350)$; total energi $(p=0,770)$; asupan karbohidrat $(p=0,968)$; protein $(p=0,663)$; natrium $(p=0,890)$; kalium $(p=0,737)$; kalsium $(p=0,768)$; magnesium $(\mathrm{p}=0,800)$; dan aktivitas fisik $(\mathrm{p}=0,682)$ dengan kekuatan otot subjek penelitian.

Simpulan : Tidak ada hubungan karakteristik subjek, asupan zat gizi, dan aktivitas fisik dengan kekuatan otot.
\end{abstract}

Kata Kunci : Kekuatan Otot, Anak Usia Sekolah, Aktivitas Fisik

\section{ABSTRACT}

Background : Muscle strength is very important to do activities, not exception for school-aged children. It's influenced by characteristics of the subject, nutrient intake, and physical activity.

Objective : To analyze the correlation between subject's characteristic, nutrient intake, and physical activity with muscle strength of school-age children in Purwakarta Regency.

Method : This study used cross sectional design. Subjects of the study were the students of Junior High School 5 Purwakarta which amounted to 44 people. Muscle strength was measured using a Hand Dynamometer, lean body mass (LBM) using Bio Impedance Analysis (BIA), nutritional intake using a 2x24 hour Food Recall Form, and physical activity using a 24-hour Physical Activity Recall Form. Data analysis using Pearson Product Moment and Mann-Whitney Test.

Result : Most of subjects' physical activity was mild (75\%). There is no correlation between age ( $p$ $=0,228) ;$ gender $(p=0,102) ; \operatorname{LBM}(p=0.350)$; total energy $(p=0.770) ;$ carbohydrate intake $(p=$ $0.968)$; protein ( $p=0.663)$; sodium $(p=0.890)$; potassium ( $p=0.737)$; calcium $(p=0.768)$; magnesium $(p=0,800)$; and physical activity $(p=0,682)$ with muscle strength of subjects.

Conclusion : There is no correlation between subject's characteristics, nutrient intake, and physical activity with muscle strength.

Keywords : Muscle Strength, School-Age Children, Physical Activity

\section{Pendahuluan}

Pendidikan anak usia sekolah sangat penting untuk perkembangan kepribadian, sikap mental, dan intelektual pada usia dini. Kualitas pendidikan anak masa awal sekolah merupakan cermin kualitas bangsa yang akan datang, akan tetapi pola pendidikan saat ini hanya menekankan pada pengembangan dari segi kognitif tanpa melibatkan aspek kesehatan jasmani anak. 
Pendidikan jasmani merupakan jenis pendidikan yang melibatkan aktifitas otot yang bertujuan untuk meningkatkan kebugaran jasmani. ${ }^{1}$ Hasil survei dari Sport Development Index (SDI) tahun 2005 tentang kebugaran jasmani pelajar SD, SMP dan SMA di seluruh Indonesia menunjukkan tingkat kebugaran yang cenderung rendah. Sama halnya pada tahun 2006, kebugaran jasmani masyarakat Indonesia berusia 25-30 tahun sebagian besar mempunyai kategori kurang $(43,90 \%)$ dan kurang sekali $(37,40 \%) .{ }^{2}$ Terdapat sebuah penelitian mengenai kebugaran jasmani yang dilakukan pada anak usia sekolah di Kabupaten Purwakarta tahun 2016, hasil penelitian menunjukkan bahwa $81,8 \%$ subjek termasuk dalam kategori kurang, $18,2 \%$ sedang, dan tidak ada subjek yang termasuk dalam kategori baik. ${ }^{3}$

Kebugaran jasmani terdiri dari berbagai komponen, salah satunya adalah kekuatan otot. ${ }^{4}$ Kekuatan otot adalah kontraksi maksimal yang dihasilkan oleh otot atau sekelompok otot melawan tahanan atau beban. ${ }^{5}$ Kekuatan otot sangat penting bagi seseorang, karena kekuatan otot yang dimiliki seseorang akan mampu melakukan aktivitas dengan baik tidak terkecuali bagi anak usia sekolah. Kegiatan di sekolah seperti menulis, menggambar, dan berolahraga sehingga dibutuhkan kontraksi otot lengan secara maksimal. Oleh karena itu, kekuatan otot lengan sangat penting utuk kelompok usia ini. Kekuatan otot dipengaruhi oleh beberapa faktor, antara lain usia, jenis kelamin, lean body mass (LBM), asupan zat gizi, dan aktivitas fisik. ${ }^{6}$ Berdasarkan latar belakang tersebut maka penelitian ini bertujuan untuk menganalisis faktor-faktor yang berhubungan dengan kekuatan otot anak usia sekolah di Kabupaten Purwakarta.

\section{Metode}

Penelitian ini merupakan jenis penelitian observasional dengan desain cross sectional. Subjek penelitian adalah siswa Sekolah Menengah Pertama (SMP) Negeri 5 Purwakarta yang berjumlah 44 orang. Pengambilan sampel dilakukan dengan teknik Stratified Sampling. Variabel terikat dalam penelitian ini adalah kekuatan otot, sedangkan variabel bebas antara lain adalah usia, jenis kelamin, lean body mass (LBM), total energi, asupan karbohidrat, asupan lemak, asupan protein, asupan natrium, asupan kalium, asupan kalsium, asupan magnesium, dan aktivitas fisik. Kekuatan otot diukur menggunakan Hand Dynamometer, lean body mass (LBM) menggunakan Bio Impedance Analysis (BIA), asupan gizi menggunakan Formulir Food Recall 2x24 jam, dan aktivitas fisik menggunakan Formulir Recall Aktivitas Fisik 24 jam. Analisis data menggunakan uji Pearson Product Moment dan Mann-Whitney Test.

\section{Hasil Penelitian \\ Karakteristik Subjek Penelitian}

Rerata usia subjek dalam penelitian ini adalah 12 tahun $(12,95 \pm 0,68$ tahun), lean body mass (LBM) adalah $33,8 \pm 5,16 \mathrm{Kg}$, dan kekuatan otot adalah 15,4 $\pm 5,01 \mathrm{Kg}$. Karakteristik subjek berdasarkan jenis kelamin, asupan zat gizi, dan aktivitas fisik terdapat dalam tabel dibawah ini (lihat tabel 1).

Tabel 1. Karakteristik Subjek Berdasarkan Jenis Kelamin, Asupan Zat Gizi, dan Aktivitas Fisik

\begin{tabular}{lllll}
\hline No. & & Variabel & n & \% \\
\hline 1 & Jenis Kelamin & & \\
& a. Laki-laki & 21 & 47,7 \\
& b. Perempuan & 23 & 52,3 \\
\hline 2 & Total Energi (\%) & & \\
a. Kurang & 37 & 84,1 \\
& b. Baik & 7 & 15,9 \\
\hline 3 & Asupan Karbohidrat (\%) & & \\
a. Defisit & 25 & 65,9 \\
& b. Kurang & 4 & 9,1 \\
& c. Sedang & 5 & 6,8 \\
\hline
\end{tabular}




\begin{tabular}{|c|c|c|c|}
\hline No. & Variabel & $\mathbf{n}$ & $\%$ \\
\hline & d. Baik & 10 & 18,2 \\
\hline \multirow[t]{5}{*}{4} & Asupan Lemak & & \\
\hline & a. Defisit & 25 & 56,8 \\
\hline & b. Kurang & 4 & 9,1 \\
\hline & c. Sedang & 5 & 11,4 \\
\hline & d. Baik & 10 & 22,7 \\
\hline \multirow[t]{5}{*}{6} & Asupan Protein & & \\
\hline & a. Defisit & 30 & 68,2 \\
\hline & b. Kurang & 5 & 11,4 \\
\hline & c. Sedang & 1 & 2,3 \\
\hline & d. Baik & 8 & 18,2 \\
\hline \multirow[t]{3}{*}{7} & Asupan Natrium & & \\
\hline & a. Kurang & 40 & 90,9 \\
\hline & b. Cukup & 4 & 9,1 \\
\hline \multirow[t]{3}{*}{8} & Asupan Kalium & & \\
\hline & a. Kurang & 44 & 100 \\
\hline & b. Cukup & 0 & 0 \\
\hline \multirow[t]{3}{*}{9} & Asupan Kalsium & & \\
\hline & a. Kurang & 41 & 93,2 \\
\hline & b. Cukup & 3 & 6,8 \\
\hline \multirow[t]{3}{*}{10} & Asupan Magnesium & & \\
\hline & a. Kurang & 37 & 84,1 \\
\hline & b. Cukup & 7 & 15,9 \\
\hline \multirow[t]{4}{*}{11} & Aktivitas Fisik & & \\
\hline & a. Ringan & 33 & 75 \\
\hline & b. Sedang & 8 & 18,2 \\
\hline & c. Berat & 3 & 6,8 \\
\hline
\end{tabular}

Sebagian besar subjek berjenis kelamin perempuan $(52,3 \%)$, sedangkan aktivitas fisik sebagian besar subjek mempunyai kategori aktivitas fisik ringan (75\%). Pada asupan zat gizi antara lain total energi $(84,1 \%)$, asupan natrium $(90,9 \%)$, asupan kalium (100\%), asupan kalsium $(93,2 \%)$, dan asupan magnesium (84,1\%) mempuyai kategori kurang, sedangkan untuk asupan karbohidrat $(65,9 \%)$, asupan lemak (56,8 \%), dan asupan protein $(68,2$ $\%)$ mempunyai kategori defisit.

\section{Hubungan Karakteristik Subjek dengan Kekuatan Otot}

Usia

Tabel 2. Hubungan Usia dengan Kekuatan Otot

\begin{tabular}{lccc}
\hline \multicolumn{1}{c}{ Variabel } & N & Mean \pm SD & p \\
\hline Umur (tahun) & 44 & $12,95 \pm 0,68$ & \multirow{2}{*}{0,228} \\
Kekuatan Otot & 44 & $15,40 \pm 5,01$ & \\
\hline
\end{tabular}

Analisis dengan menggunakan Pearson Product Moment Test

Tingkat kepercayaan $95 \%$ signifikan jika nilai $\mathrm{p} \leq 0,05$

Hasil analisis data diatas menunjukkan bahwa tidak ada hubungan antara usia subjek penelitian dengan kekuatan otot $(\mathrm{p}=0,228)$. 


\section{Jenis Kelamin}

Tabel 3. Perbedaan Kekuatan Otot Berdasarkan Jenis Kelamin

\begin{tabular}{lccc}
\hline \multicolumn{1}{c}{ Jenis Kelamin } & N & Mean \pm SD & p \\
\hline Laki-laki & 21 & $16,80 \pm 5,21$ & \multirow{2}{*}{0,102} \\
Perempuan & 23 & $14,11 \pm 4,56$ & \\
\hline
\end{tabular}

Analisis dengan menggunakan Mann Whitney Test

Tingkat kepercayaan 95\% signifikan jika nilai $\mathrm{p} \leq 0,05$

Analisis data diatas menunjukkan bahwa tidak ada perbedaan kekuatan otot antara subjek penelitian laki-laki dan perempuan $(p=0,102)$, hal ini menunjukkan bahwa jenis kelamin tidak berhubungan dengan kekuatan otot.

\section{Lean Body Mass (LBM)}

Penghitungan lean body mass (LBM) didasarkan pada selisih antara berat badan dan persentase lemak tubuh. Hasil analisis hubungan LBM dengan kekuatan otot menunjukkan bahwa tidak ada hubungan LBM subjek penelitian dengan kekuatan otot $(p=0,350)$. Data selengkapnya dapat dilihat pada Tabel 4.

Tabel 4. Hubungan Lean Body Mass (LBM) dengan Kekuatan Otot

\begin{tabular}{lccc}
\hline \multicolumn{1}{c}{ Variabel } & N & Mean \pm SD & p \\
\hline Lean Body Mass (Kg) & 44 & $33,80 \pm 5,16$ & 0,350 \\
Kekuatan Otot (Kg) & 44 & $15,40 \pm 5,01$ & \\
\hline
\end{tabular}

Analisis dengan menggunakan Pearson Product Moment Test

Tingkat kepercayaan $95 \%$ signifikan jika nilai $\mathrm{p} \leq 0,05$

\section{Hubungan Asupan Zat Gizi dengan Kekuatan Otot Total Energi}

Tabel 5. Hubungan Total Energi dengan Kekuatan Otot

\begin{tabular}{lccc}
\hline \multicolumn{1}{c}{ Variabel } & N & Mean \pm SD & p \\
\hline Total Energi (\%) & 44 & $69,92 \pm 37,76$ & \multirow{2}{*}{0,770} \\
Kekuatan Otot (Kg) & 44 & $15,40 \pm 5,01$ & \\
\hline
\end{tabular}

Analisis dengan menggunakan Pearson Product Moment Test

Tingkat kepercayaan $95 \%$ signifikan jika nilai $\mathrm{p} \leq 0,05$

Hasil analisis menunjukkan bahwa total energi subjek dalam penelitian ini tidak berhubungan dengan kekuatan otot $(\mathrm{p}=0,770)$.

\section{Asupan Karbohidrat}

Tabel 6. Hubungan Asupan Karbohidrat dengan Kekuatan Otot

\begin{tabular}{lccc}
\hline \multicolumn{1}{c}{ Variabel } & N & Mean \pm SD & p \\
\hline Asupan Karbohidrat (\%) & 44 & $69,44 \pm 41,43$ & \multirow{2}{*}{0,774} \\
Kekuatan Otot (Kg) & 44 & $15,40 \pm 5,01$ & \\
\hline
\end{tabular}

Analisis dengan menggunakan Pearson Product Moment Test

Tingkat kepercayaan $95 \%$ signifikan jika nilai $\mathrm{p} \leq 0,05$

Hasil analisis menunjukkan bahwa asupan karbohidrat subjek dalam penelitian ini tidak berhubungan dengan kekuatan otot $(\mathrm{p}=0,774)$.

\section{Asupan Lemak}

Tabel 7. Hubungan Asupan Lemak dengan Kekuatan Otot

\begin{tabular}{cccc}
\hline Variabel & N & Mean \pm SD & p \\
\hline Asupan Lemak (\%) & 44 & $76,18 \pm 45,54$ & \multirow{2}{*}{0,968} \\
Kekuatan Otot (Kg) & 44 & $15,40 \pm 5,01$ & \\
\hline Analisis dengan menggunakan Pearson Product Moment Test &
\end{tabular}


Tingkat kepercayaan 95\% signifikan jika nilai $\mathrm{p} \leq 0,05$

Hasil analisis menunjukkan bahwa asupan lemak subjek dalam penelitian ini tidak berhubungan dengan kekuatan otot $(\mathrm{p}=0,968)$.

\section{Asupan Protein}

Tabel 8. Hubungan Asupan Protein dengan Kekuatan Otot

\begin{tabular}{lccc}
\hline Variabel & N & Mean \pm SD & p \\
\hline Asupan Protein (\%) & 44 & $74,40 \pm 46,53$ & \multirow{2}{*}{0,663} \\
Kekuatan Otot (Kg) & 44 & $15,40 \pm 5,01$ & \\
\hline
\end{tabular}

Analisis dengan menggunakan Pearson Product Moment Test

Tingkat kepercayaan $95 \%$ signifikan jika nilai $\mathrm{p} \leq 0,05$

Hasil analisis menunjukkan bahwa asupan protein subjek dalam penelitian ini tidak berhubungan dengan kekuatan otot $(0,663)$.

\section{Asupan Natrium}

Tabel 9. Hubungan Asupan Natrium dengan Kekuatan Otot

\begin{tabular}{lccc}
\hline \multicolumn{1}{c}{ Variabel } & N & Mean \pm SD & p \\
\hline Asupan Natrium $(\mathrm{mg})$ & 44 & $623,33 \pm 638,76$ & \multirow{2}{*}{0,890} \\
Kekuatan Otot $(\mathrm{Kg})$ & 44 & $15,40 \pm 5,01$ & \\
\hline
\end{tabular}

Analisis dengan menggunakan Pearson Product Moment Test

Tingkat kepercayaan $95 \%$ signifikan jika nilai $\mathrm{p} \leq 0,05$

Hasil analisis menunjukkan bahwa asupan natrium subjek dalam penelitian ini tidak berhubungan dengan kekuatan otot $(\mathrm{p}=0,890)$.

\section{Asupan Kalium}

Tabel 10. Hubungan Asupan Kalium dengan Kekuatan Otot

\begin{tabular}{lccc}
\hline \multicolumn{1}{c}{ Variabel } & N & Mean \pm SD & p \\
\hline Asupan Kalium $(\mathrm{mg})$ & 44 & $1065 \pm 837,44$ & \multirow{2}{*}{0,737} \\
Kekuatan Otot $(\mathrm{Kg})$ & 44 & $15,40 \pm 5,01$ & \\
\hline Anglis &
\end{tabular}

Analisis dengan menggunakan Pearson Product Moment Test

Tingkat kepercayaan $95 \%$ signifikan jika nilai $\mathrm{p} \leq 0,05$

Hasil analisis menunjukkan bahwa asupan kalium subjek dalam penelitian ini tidak berhubungan dengan kekuatan otot $(\mathrm{p}=0,737)$.

\section{Asupan Kalsium}

\begin{tabular}{lccc}
\multicolumn{4}{c}{ Tabel 11. Hubungan Asupan Kalsium dengan Kekuatan Otot } \\
\hline \multicolumn{1}{c}{ Variabel } & $\mathbf{N}$ & Mean \pm SD & p \\
\hline Asupan Kalsium (mg) & 44 & $339,23 \pm 509,96$ & 0,768 \\
Kekuatan Otot (Kg) & 44 & $15,40 \pm 5,01$ & \\
\hline
\end{tabular}

Analisis dengan menggunakan Pearson Product Moment Test

Tingkat kepercayaan $95 \%$ signifikan jika nilai $\mathrm{p} \leq 0,05$

Hasil analisis menunjukkan bahwa asupan kalsium subjek dalam penelitian ini tidak berhubungan dengan kekuatan otot $(\mathrm{p}=0,768)$. 


\section{Asupan Magnesium}

Tabel 12. Hubungan Asupan Kalium dengan Kekuatan Otot

\begin{tabular}{lccc}
\hline \multicolumn{1}{c}{ Variabel } & N & Mean \pm SD & p \\
\hline Asupan Magnesium $(\mathrm{mg})$ & 44 & $155,12 \pm 68,3$ & \multirow{2}{*}{0,800} \\
Kekuatan Otot $(\mathrm{Kg})$ & 44 & $15,40 \pm 5,01$ & \\
\hline
\end{tabular}

Analisis dengan menggunakan Pearson Product Moment Test

Tingkat kepercayaan 95\% signifikan jika nilai $\mathrm{p} \leq 0,05$

Hasil analisis menunjukkan bahwa asupan magnesium subjek dalam penelitian ini tidak berhubungan dengan kekuatan otot $(\mathrm{p}=0,800)$.

\section{Aktivitas Fisik}

Pada penelitian ini aktivitas fisik diukur dengan formulir recall aktivitas 24

jam. Analsis hubungan aktivitas fisik dengan kekuatan otot dapat dilihat pada Tabel 13. Tabel 13. Hubungan Aktivitas Fisik dengan Kekuatan Otot

\begin{tabular}{lccc}
\hline \multicolumn{1}{c}{ Variabel } & N & Mean \pm SD & p \\
\hline Aktivitas Fisik & 44 & $1,52 \pm 0,41$ & \multirow{2}{*}{0,682} \\
Kekuatan Otot (Kg) & 44 & $15,40 \pm 5,01$ & \\
\hline
\end{tabular}

Analisis dengan menggunakan Pearson Product Moment Test

Tingkat kepercayaan 95\% signifikan jika nilai $\mathrm{p} \leq 0,05$

Hasil analisis menunjukkan bahwa aktivitas fisik subjek dalam penelitian ini tidak berhubungan dengan kekuatan otot $(\mathrm{p}=0,682)$.

\section{Pembahasan}

Subjek dalam penelitian ini sebagian besar mempunyai kategori asupan kurang dan defisit. Hasil food recall 2x24 jam terlihat bahwa subjek penelitian cenderung mengkonsumsi makanan yang tidak bervariasi dengan porsi makanan yang kecil. Asupan gizi yang baik sangat penting bagi anak sekolah. Kemampuan anak untuk dapat mengembangkan kemampuan saraf motoriknya adalah melalui pemberian asupan gizi yang seimbang. Asupan gizi yang kurang menyebabkan anak tidak dapat melakukan aktivitas fisik secara optimal. Hal ini terlihat pada hasil recall aktivitas fisik, dimana sebagian besar subjek (75\%) mempunyai kategori aktivitas fisik ringan. Sama halnya dengan penelitian yang dilakukan oleh Ridwan dkk tahun 2016 pada siswa sekolah dasar bahwa semua subjek yang diteliti (100\%) mempunyai kategori aktivitas fisik ringan. ${ }^{3}$

Aktivitas fisik berperan penting dalam kekuatan otot, seperti disebutkan dalam sebuah penelitian yang dilakukan oleh William et al tahun 2005 bahwa aktivitas fisik anak dan remaja usia sekolah berhubungan dengan kekuatan otot tubuh. Dalam penelitian tersebut juga menyebutkan bahwa subjek yang melakukan aktivitas fisik secara rutin dalam bentuk olahraga sebesar $2-3$ kali seminggu dapat meningkatkan kekuatan otot dibandingkan yang tidak melakukan aktivitas fisik secara rutin. ${ }^{7}$ Hasil recall aktivitas fisik menunjukkan bahwa sebagian besar subjek penelitian tidak melakukan olahraga sehingga mempunyai kecenderungan tidak ada peningkatan kekuatan otot.

Asupan gizi subjek dalam penelitian ini sebagian besar mempunyai kategori kurang dan defisit. Hal ini dapat terlihat pada hasil food recall 2x24 jam bahwa sebagian besar subjek tidak mengkonsumsi makanan yang beragam sehingga kebutuhan zat gizi kurang terpenuhi. Rerata kekuatan otot subjek adalah 15,40 \pm 5,01 Kg sehingga dikategorikan lemah. Sama halnya dengan penelitian yang dilakukan pada siswa SMK di Denpasar tahun 2014 bahwa rerata kekuatan otot subjek mempunyai kategori sangat lemah. ${ }^{8}$

Analisis menunjukkan bahwa usia, jenis kelamin, lean body mass (LBM), total energi, asupan karbohidrat, asupan lemak, asupan protein, asupan natrium, asupan kalium, asupan kalsium, asupan magnesium, dan aktivitas fisik tidak 
berhubungan dengan kekuatan otot $(\mathrm{p}>0,05)$. Hal ini sejalan dengan penelitian yang dilakukan oleh Ridwan dkk (2016) bahwa tidak ada hubungan aktivitas fisik dan asupan energi dengan kebugaran jasmani. ${ }^{3}$ Kekuatan otot dalam penelitian ini kemungkinan dipengaruhi oleh variabel lain yang bersifat non teknis, misalnya adalah terkait dengan faktor psikologis subjek yang sedang tidak mood selama proses penelitian yang belum dapat diteliti dalam penelitian ini.

\section{Simpulan}

Sebagian besar (75\%) aktivitas fisik subjek dalam penelitian ini tergolong kurang. Begitu pula dengan asupan gizi, sebagian besar subjek tergolong kurang dan defisit. Semua variabel dalam penelitian ini tidak berhubungan dengan kekuatan otot subjek $(p>0,05)$, sehingga dimungkinkan terdapat faktor lain yang mempengaruhi, seperti keadaan psikologis subjek pada saat penelitian.

\section{Daftar Pustaka}

1. Abdul Kadir Ateng. 1992. Asas dan Landasan Pendidikan Jasmani. Jakarta : Depdikbud Dirjen Dikti.

2. Maksum, A. Sport Development Index Bukan Kontra Prestasi. Diunduh dari
URL:

http://www.bulutangkis.com/mod.php ?mod=publisher\&op=viewarticle\&artid =3026. Di akses pada 13 Mei 2016 .

3. Muhammad R, Naintina L, Emilia EP. Hubungan Antara Asupan Energi dan Aktifitas Fisik dengan Kebugaran Jasmani. Journal of Holistic and Health Sciences. 2017; 1(1) : 73 - 85.

4. Sumosardjuno, Sudoso. 1986. Pengetahuan Praktis Kesehatan dalam Olah raga. Jakarta : PT.Gramedia Pustaka Utama. Jakarta.

5. Dwikusworo EP. 2010. Tes Pengukuran dan Evaluasi Olahraga. Semarang: Widya Karya.

6. Mehrsheed S, Paul JL, Peter CW, John WG, Paul AM. Correlation of Trunk Muscle Strenght with Age in Children 5 to 18 Years Old. Mayo Clin Proc. 1996; 71: 1047 - 54 .

7. William et al. Evidence Based Physical Activity For School-Age Youth. J Pediatr. 2005;146:732-7.

8. Ramadas DR. Karakteristik Kekuatan Otot, Kelenturan Tubuh, Komposisi Tubuh dan Indeks Massa Tubuh Siswa SMK Negeri 5 Denpasar Tahun Ajaran 2014/2015. ISM. 2015;5(1):36-42. 